\title{
Biochemical Biomarkers of Exposure to Deltamethrin in Freshwater Fish, Ancistrus multispinis
}

\author{
Helena Cristina da Silva de Assis ", Lilian Nicareta, Ligia Maria Salvo, Claudio Klemz, \\ Jessé Henrique Truppel and Rossana Calegari \\ ${ }^{I}$ Departamento de Farmacologia; Universidade Federal do Paraná; C. P.: 19031; 81531-990; Curitiba - PR - \\ Brasil
}

\begin{abstract}
This study aimed to determine the effect of sublethal doses of deltamethrin, using biochemical biomarkers as activities of cholinesterase (ChE), ethoxyresorufin-O-deethylase (EROD) and the $\mathrm{Na}^{+} \mathrm{K}^{+}$- ATPase and levels of total cytochrome P450 (CYP450). Fishes received sublethal doses of deltamethrin and were sacrificed after 96 h of exposure. Samples of gills, heart, brain, liver and muscle were collected for enzymatic analyses. Deltamethrin inhibited the activity of the gills and heart $\mathrm{Na}^{+} \mathrm{K}^{+}$-ATPase, induced the liver total CYP450, as well as the liver EROD activity. The activity of the ChE was not inhibited by deltamethrin. Deltamethrin altered the hepatic metabolism and the normal ionic flux in Ancistrus multispinis.
\end{abstract}

Key words: deltamethrin, cytochrome P450, fish, Ancistrus multispinis, biomarker

\section{INTRODUCTION}

Pyrethroids are synthetic derivatives of pyrethrins, which are toxic components contained in the flowers of Chrysanthemum cinerariaefolium. Although synthetic pyrethroids are less persistent and less toxic to mammals and birds (Sayeed et al, 2003), they are highly toxic to a number of nontarget organisms such as bees, freshwater fish and other aquatic organisms even at very low concentrations (Oudou et al, 2004). For this reason, these organisms are extremely sensitive to neurotoxic effects of pyrethroids when they reach surface water-courses (Bradbury and Coats 1989, Haya, 1989; Mittal et al, 1994). One of the pyrethroids that has found wide acceptability and is extremely used in agriculture and forestry because of its high activity against a broad spectrum of insect pests (Villarini et al, 1998) is deltamethrin ((S) $\alpha$-cyano-3-phenoxybenzyl-(1R)cis-3-(2.2-dibromovinyl)-2,2- dimethyl cyclopropane carboxylate). However, its effects on nervous, respiratory, and hematological systems in fishes have been reported (Ural and Sağlam, 2005, Pimpão et al, 2007).

Bálint et al (1995) observed 20\% decrease in acetylcholinesterase activity of brain, heart, blood, liver and skeletal muscle of carp after the 3 days exposure to deltamethrin. In rats, the main reaction involved in the metabolism of deltamethrin is ester cleavage, by CYP450 and carboxyesterase action. Metabolism in fish is largely oxidative and deficient in esterases metabolization (Demoute, 1989). ATPase has been demonstrated to be one of the targets of pyrethroids. Some authors showed that ATPase including cell membrane-associated

*Author for correspondence: helassis@ufpr.br 
$\mathrm{Na}^{+}-\mathrm{K}^{+}$and $\mathrm{Ca}^{2+} \mathrm{Mg}^{2+}$-ATPase, mitochondrial $\mathrm{Mg}^{2+}$ and $\mathrm{Ca}^{2+}$-ATPase could be inhibited by DDT (dichlorodiphenyltrichloroethane) and pyrethroids (Clark and Matsumura, 1987, Al-Rajhi, 1990).

Biomarkers are measurable response at the first levels of biological organization and have been used to evaluate exposure to environmental pollutants (Walker et al 1996, Pikkarainen, 2006). Standardization of biomarkers for detection of sublethal effects in native species, such as Ancistrus multispinis under laboratory conditions enable the biomonitoring in natural conditions in order to detect the pollution interferences in early stages of interaction with the environment. Ancistrus multispinis (Regan, 1912) (Siluriformes, Loricariidae) (cascudo) is a fresh-water fish, native to the southern region of Brazil. It was chosen for this study due to its detritivorous habit, meaning that the fish has been in contact with xenobiotics, such as deltamethrin that interact with algae from stone or sediment and also for its tolerance to hypoxia and facility to be kept in laboratory (Klemz and Silva de Assis, 2005).

This work aimed to evaluate the effects of sublethal doses of deltamethrin on the stated biomarkers in Ancistrus multispinis.

\section{MATERIAL AND METHODS}

\section{Fish}

Fishes were acquired from the pet store and transferred to the lab, maintained in $120 \mathrm{~L}$ aquaria with aeration and biological filtration. These were maintained under constant temperature $\left(23^{\circ} \mathrm{C} \pm 2\right)$, controlled $\mathrm{pH}(7.3 \pm 0.2)$ and photoperiod $(12 \mathrm{~h}$ dark/12 h light) and fed "ad Libitum" with commercial ration. Male and female fishes weighed $10.7 \pm 0.75 \mathrm{~g}$ (mean \pm standard deviation).

\section{Experimental design}

Technical grade deltamethrin (DM, 98.8\% pure) was supplied by Aventis CropScience Brazil (São Paulo, Brazil). Fishes were randomly taken, measured, weighed and grouped in number of 12 in 30 liters test aquaria. Induced group (positive control) received an intracoelomic (IC) injection of 3-methylcholantrene (3-MC) (30 mg. $\left.\mathrm{kg}^{-1}\right)$, which induced CYP1A isoforms. Control group received an IC injection of sunflower oil. Test groups received an IC injection with two sub lethal doses of DM (0.3 OR $\left.0.4 \mathrm{mg} \cdot \mathrm{kg}^{-1}\right)$. $\mathrm{DL}_{50} 96 \mathrm{~h}$ for deltamethrin $\left(0.5 \mathrm{mg} \cdot \mathrm{kg}^{-1}\right)$ was determined in the laboratory in previous studies (data not published). All the groups were kept under the same experimental conditions for $96 \mathrm{~h}$. The experiment was carried out in duplicate. Fishes were sacrificed and liver was removed, washed with saline solution and immediately frozen in liquid nitrogen. The heart, gills, brain, muscle were also taken and frozen $\left(-70^{\circ} \mathrm{C}\right)$ for enzymatic analysis

\section{Biochemical Assays}

Axial muscle samples (200-300 mg) were homogenized in Potter-Elvejhem in $2 \mathrm{ml}$ phosphate buffer (0.1M, pH7.5). Homogenates were centrifuged for 10 minutes at $10,000 \times g$ at $4^{\circ} \mathrm{C}$. Muscle cholinesterase activity was analyzed by Ellman et al (1961) method, adapted for microplate by Silva de Assis (1998). For the $\mathrm{Na}^{+} \mathrm{K}^{+}$-ATPase activity, left gills filaments, heart and brain were homogenized in buffer $\mathrm{pH} 7.4(0.3$ M sacarose, $0.1 \mathrm{mM} \mathrm{Na}_{2}$ EDTA, $30 \mathrm{mM}$ imidazol, $10 \mathrm{mM} \beta$-mercaptoetanol) and centrifuged for 5 minutes at $10,000 \times g$ at $4^{\circ} \mathrm{C}$. Saponin solution was added to the supernatant.

The $\mathrm{Na}^{+} \mathrm{K}^{+}$-ATPase activity was determined by measuring the initial rate of release of Pi from ATP. It was measured ouabain sensitive ATP. Ouabain sensitive ATP hydrolysis was measure according to $\mathrm{Li}$ et al (1998). Free inorganic phosphate was detected by the ammonium molybdate reagent. All the assays were carried out in triplicate and run with enzyme and reaction blank. ATPase activity was normalized by protein concentration in crude homogenate and expressed as $\mu \mathrm{mol} \mathrm{P}_{\mathrm{i}} \cdot \mathrm{mg}$ protein ${ }^{-1} \cdot \mathrm{h}^{-1}$.

The S9 and microssomal liver fractions were obtained from liver, following Stegemann et al, (1979) method. Livers samples were thawed and homogenized in four volumes of homogenization buffer $\left(0.08 \mathrm{M} \mathrm{Na}_{2} \mathrm{HPO}_{4} ; 0.02 \mathrm{M} \mathrm{KH}_{2} \mathrm{PO}_{4} ; 0.15 \mathrm{M}\right.$ $\mathrm{KCl}, \mathrm{pH}$ 7.4). Homogenate was centrifuged at $10,000 \times \mathrm{g}$ for $20 \mathrm{~min}$ at $4^{\circ} \mathrm{C}$. The supernatant was ultracentrifuged at $100,000 \times \mathrm{g}$ for $60 \mathrm{~min}$ at $4^{\circ} \mathrm{C}$. The pellet was resuspended in $1 \mathrm{ml}$ of resuspension buffer (homogenization buffer with 20\% glycerol, $\mathrm{v} / \mathrm{v})$ to obtain the hepatic microssomal fraction which was used for all spectroscopic CYP analysis.

Analysis of total cytochrome P450 (CYP) was based on the methods described before (Omura and Sato, 1964, Johannesen and Depierre, 1978) 
using differential visible spectroscopy. The EROD was measured according to Burke and Mayer (1974), modified by Silva de Assis (1998). Protein concentration was determined by Bradford (1976) method, using bovine serum albumin (BSA) as a standard.

\section{Statistical analysis}

Data were expressed as mean \pm standard error of the means (s.e.m.) and were analysed by analysis of variance (ANOVA), followed by Bonferroni's test for the post-hoc comparisons. The significance of results was ascertained at $\mathrm{p}<0.05$.

\section{RESULTS}

Total cytochrome P450 (CYP) was induced in the fishes exposed to the higher doses $\left(0.4 \mathrm{mg} \cdot \mathrm{kg}^{-1}\right)$, compared to control group. As expected, positive control (3MC) showed higher CYP concentration (Fig. 1).

EROD activity was induced by the two tested doses of deltamethrin in the microssomal fraction. In the S9 fraction only the higher dose caused induction (Fig. 2).

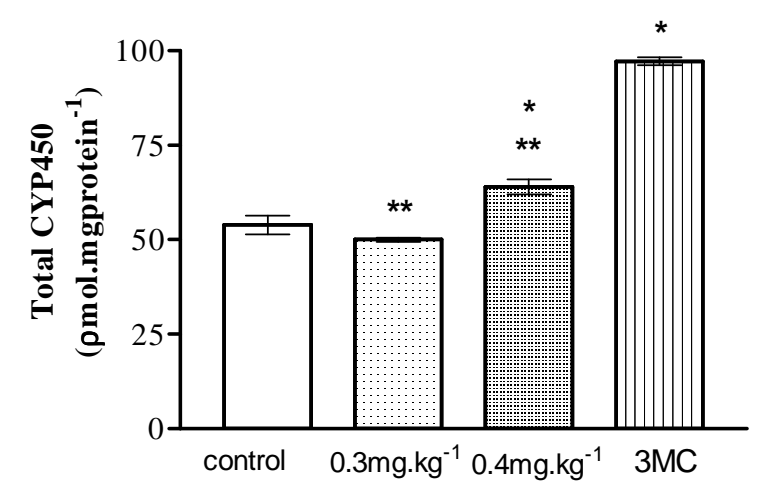

Figure 1 - Total cytochrome in liver of A multispinis. * $\mathrm{p}<0.05$ compared to control groups; ** $\mathrm{p}<0.001$ compared to 3MC (ANOVA).

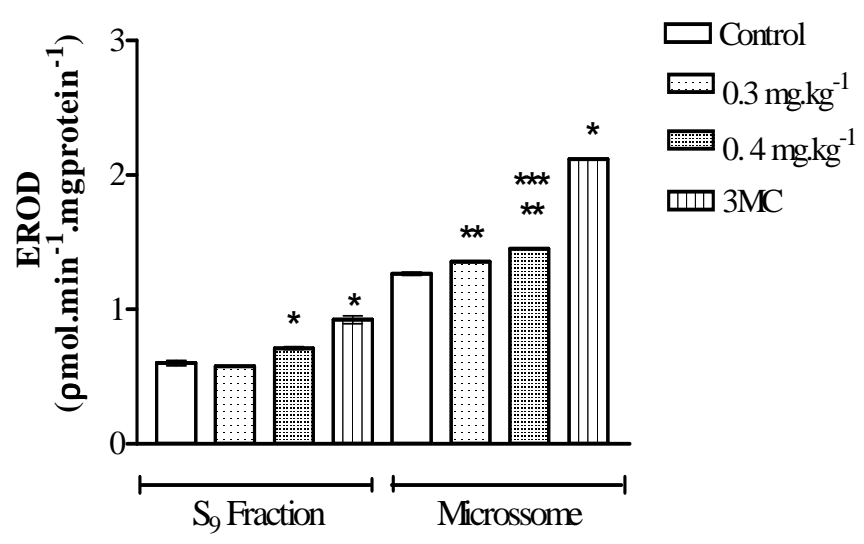

Figure 2 - EROD activity in liver of $A$ multispinis. $* \mathrm{p}<0.01$ compared to $\mathrm{S}_{9}$ and microssomal fractions control; ** $\mathrm{p}<0.001$ compared to microssomal fraction control; $* * * \mathrm{p}<0.01$ compared to deltamethrin $\left(0.3 \mathrm{mg} \cdot \mathrm{kg}^{-1}\right.$ in the microssomal fraction (ANOVA). 
The heart $\mathrm{Na}^{+} \mathrm{K}^{+}$-ATPase was inhibited by deltamethrin in the doses of 0.3 and $0.4 \mathrm{mg} \cdot \mathrm{kg}^{-1}$ (Fig. 3). The percentage of inhibition is shown in parenthesis. In gills, only the higher dose caused inhibition (Fig. 4) and in brain, no significant difference from control group was observed (data not shown).

The ChE activity was not inhibited in the both doses of deltamethrin.

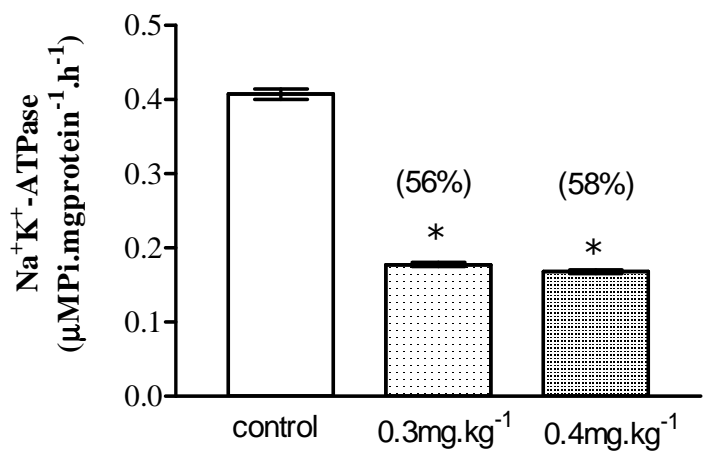

Figure $3-\mathrm{Na}^{+} \mathrm{K}^{+}$-ATPase in heart of A multispinis. $* \mathrm{p}<0.05$ (ANOVA).

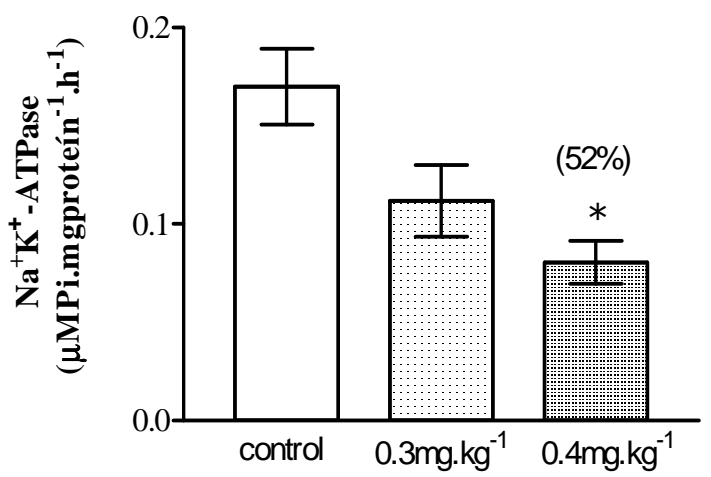

Figure $4-\mathrm{Na}^{+} \mathrm{K}^{+}$-ATPase in gills of A multispinis. $* \mathrm{p}<0.05$ (ANOVA).

\section{DISCUSSION}

Total CYP450 and EROD activity of $A$. multispinis were induced by deltamethrin. The induction of specific isoenzymes of cytochrome $\mathrm{P} 450$ is a sensitive response of an organism to exposure to certain anthropogenic chemicals (e.g. PAHs, coplanar PCBs, polychlorinated biphenys (PCB), polychlorinated dibenzofurans (PCDF) and the dibenzodioxins (Stegeman and Hahn, 1994). This exposure leads to a selective, receptormediated stimulation of the CYP1A gene transcription rate, resulting in increased levels of specific mRNA, new synthesis of cytochrome
P450 isoenzymes (CYP1A), and an increase in the respective catalytic activities (e.g. EROD) (Bucheli and Fent 1995.). Knowledge of structureinduction relationships in fish is limited and doseresponse effects have been established for few compounds (Melacon and Lech, 1983, Stegeman et al 1990, Hestermann et al, 2000). Due to the fact that deltamethrin structure is not similar to the PCBs and PAHs, for example, the mechanism of induction can not be explained based on relationship between induction and chemical structure of deltamethrin. Therefore, other studies also observed the increase of CYP1A1/1A2 and the EROD activity by deltamethrin in liver and 
brain of Wistar rats (Dayal et al, 1999), but they did not explain the induction mechanism. Further studies must be done to elucidate this mechanism. In this study, the total CYP450 was induced in the higher dose, while the EROD activity was induced in the both doses, probably due to EROD`s higher detection sensitivity. The total CYP450 becomes less sensitive when simple compounds are inducers for same enzymes and inhibitors for others isoenzymes. This can alter the total concentration or isoenzyme activity without altering the total CYP450 (Miranda et al, 1990). In this study, the CYP of A. multispinnis showed to be inducible to Ah-ligand as 3-MC. This was in agreement with studies that have been carried out on the induction of hepatic CYP1A in the fishes by AhR-binding ligands, such as $3 \mathrm{MC}$ and $\mathrm{BNF}, \beta-$ naphtoflavone (Goksøyr and Förlin, 1992; Stegeman and Hahn, 1994).

The ChE activity in muscle was not inhibited in $A$. multispinis after deltamethrin exposure. Although not data about deltamethrin effects in this species of fish have been shown in the literature, inhibition results were found by pyrethroids in other fish species (Reddy and Philip, 1994, Szegletes et al , 1995; Bálint et al, 1995), including deltamethrin. According to Sturm et al, (1999), the no enzymespecific pollutants need to be in high concentration to cause inhibition (Sturm et al 1999).

In this study, deltamethrin inhibited the gills and heart $\mathrm{Na}^{+} \mathrm{K}^{+}$-ATPase activity of A. multispinnis. Cipermethrin, also a pyrethroid, caused ATPase inhibition in brain, liver and kidney of carps exposed during 45 days (Das and Mukherjee, 2003). It could inhibited the sodium ions transport through the membrane, disrupting the cell ionic balance, which could be due to different enzyme isoforms in different tissues and specifically $\alpha$ isoforms, responsible for catalytic activity. The isoforms of the $\mathrm{Na}^{+} \mathrm{K}^{+}$-ATPase subunity $\alpha$ could be distributed differently according to the tissue and different substrate affinity (ion) and to ouabain (Blanco and Mercer 1998), besides the different vias of hormonal regulation and/or to quinasesprotein (Therien and Blostein, 2000). ATPases are considered to be involved in the maintenance of ionic balance in the gills. The alteration in these enzymes activities could cause an ionic imbalance and affect other vital processes associated with gills. Inhibition of total ATPase, ouabain-insensitive ATPase, and $\mathrm{Na}^{+} \mathrm{K}^{+}$-ATPase activity in the gills of $C$. punctata exposed to paper mill effluent was observed, with maximum impairment in $\mathrm{Na}^{+} \mathrm{K}^{+}$-ATPase activity (Parvez et al, 2006). Deltamethrin altered the normal ion flux in A. multispinis.

\section{ACKNOWLEDGEMENTS}

The authors gratefully acknowledge the technical support from the Department of Phisyology, Federal University of São Carlos.

\section{RESUMO}

Deltametrina é um inseticida piretroide, usado in agricultura, na medicina veterinária a em saúde pública devido a sua baixa toxicidade para mamíferos. Contudo, para espécies não alvo como os peixes a deltametrina é extremamente tóxica. Esse estudo tem por objetivo determinar o efeito de doses subletais de deltametrina, usando biomarcadores bioquímicos como atividade da colinesterase $(\mathrm{ChE})$, níveis totais de citocromo P450 (CYP450), atividade da ethoxyresorufin-Odeethylase (EROD) e da $\mathrm{Na}^{+} \mathrm{K}^{+}$-ATPase. Os peixes receberam doses subletais de deltametrina $\mathrm{e}$ após 96 horas de exposição foram sacrificados e o fígado, brânquias, coração e músculo foram coletados para as medidas enzimáticas. A atividade da $\mathrm{Na}^{+} \mathrm{K}^{+}$-ATPase em brânquias e coração foi inibida. A deltametrina aumentou os níveis de CYP450 total, bem como a atividade da EROD. A atividade da $\mathrm{ChE}$ não foi inibida. Deltametrina alterou a atividade da $\mathrm{Na}^{+} \mathrm{K}^{+}$-ATPase e desta forma o fluxo normal de ions em A. multispinnis, bem como seu metabolismo hepático. Os efeitos detectados através de biomarcadores tornam esse inseticida um importante contaminante para organismos aquáticos.

\section{REFERENCES}

Al-Rajhi, D. H. (1990), Properties of $\mathrm{Ca}^{2+}+\mathrm{Mg}^{2+}$ ATPase from rat brain and its inhibition by pyrethroids. Pest. Biochem. Physiol., 37, 116-120.

Bálint, T., Szegletes, T., Szegletes, Z., Halasy, K., Nemcsók, J. (1995), Biochemical and subcellular changes in carp exposed to the organophosphorous metidation and the pyrethroid deltamethrin. Aquat. Toxicol. , 33, 279-295. 
Blanco, G., Mercer, R. W., (1998), Isozymes of the $\mathrm{Na}^{+} \mathrm{K}^{+}$-ATPase: heterogeneity in structure, diversity in function. Am. J. Physiol., 275, 633-650.

Bradbury, S. P., Coats, J. R. (1989), Comparative toxicology of the pyrethroid insecticides. Rev. Environ. Contam. Toxicol., 108, 133-177.

Bradford, M. (1976). A Rapid and sensitive method for the quantification of microgram quantities of protein utilizing the principle of protein-dye binding. Anal. Biochem., 72, 248-254.

Bucheli, T. B., Fent, K. (1995), Induction of cytochrome $\mathrm{P} 450$ as a biomarker for environmental contamination in aquatic ecosystems. Crit. Rev. Environm. Sci. Technol., 25, 201-268.

Burke, M. D., Mayer, R. T. (1974), Ethoxyresorufin: direct fluorimetric assay of a microsomal Odealkylation which is preferentially inducible by 3methylcholantrene. Drug Metab. Dispos., 2, 583-588.

Clark, J. M., Matsumura, F. (1987), The action of two classes of pyrethroids on the inhibition of brain $\mathrm{Na}$ $\mathrm{Ca}$ and $\mathrm{Ca}^{+} \mathrm{MgATP}$ hydrolyzing activities of the American cockroach. Comp. Biochem. Physiol., 86, 135-145.

Das, B. K., Murkerjee, S. C. (2003), Toxicity of cypermethrin in Labeo rohita fingerlings: biochemical, enzymatic and haematological consequences. Comp.Physiol., 134, 109-121.

Dayal, M., Parmar, D., Dhawan, A., Dwivedi, U. N., Doehmer, J., Seth, P. K. (1999), Induction of rat brain and liver cytochrome P450A1A/1A2 and 2B1/2B2 isoenzymes by deltamethrin. Environ. Toxicol. Pharmacol., 27, 169-178.

Demoute, J. P. (1989), A brief review of the environmental fate and metabolism of pyrethroids. Pest. Sci. 27, 375-385.

Ellman, G. L., Coutney, K. O., Andres, V., Featherstone, R.M., (1961), A new and rapid colorimetric determination of acetylcholinesterase activity. Biochem. Pharmacol., 7, 88-95.

Haya, K., (1989), Toxicity of pyrethroid insecticide to fish, Environ. Toxicol. Chem. 8, 381-391.

Hestermann, E. V., Stegeman, J. J., Hahn, M. E. (2000), Relative contributions of affinity and intrinsic efficacy to aryl hydrocarbon receptor ligand potency. Toxicol. App. Pharmacol., 168, 160-172.

Johannesen, K. A. M., Depierre, J. W. (1978), Measurement cytochrome $\mathrm{P} 450$ in the presence of large amounts of contaminating hemoglobin and methemoglobin. Anal. Biochem., 86, 725-732.

Klemz, C. (20002), Uso de Biomarcadores de Contaminação Ambiental em Peixes Ancistrus sp (Cascudo), Federal Paraná University, Curitiba, Pr, Brasil.

Li, J., Quabius, E. S., Wendelaar Bonga, S. E., Flik, G., Lock, R. A. C. (1998), Effects of water-borne copper on branchial chloride cells and $\mathrm{Na}+\mathrm{K}+-$ ATPAase activities in Mozambique tilapia (Oreochromis mossambicus). Aquat. Toxicol., 4, 51-61.
Miranda, C. L., Wang, J. L., Chang, H. S., Buhler, D. R. (1990), Multiple effects of 3,4,5,3',4',5'hexachlorobiphenyl administration on hepatic cytochrome P450 isozymes and associated mixedfunction oxidase activities in rainbow trout. Biochem. Pharmacol., 40, 387.

Mittal, K., Adak, T., Sharma, V. P. (1994), Comparative toxicity of certain mosquitocidal compounds to larvivorous fish, Poecilia reticulata, Ind. J. Malariol., 31, 43-47.

Omura, T., Sato, R. (1964), The carbon monoxidebinding pigment of liver microsomes. I. Evidence for its hemoprotein nature. J. Biol. Chem., 239, 23702378.

Oudou, H. C., Alonso, R. M., Bruun Hansen, H. C. (2004), Voltammetric behavior of the synthetic pyrethroid lambda-cyhalothrin and its determination in soil and well water. Anal. Chim. Acta, 523, 69-74.

Parvez, S., Sayeed, I., Raisuddin, S. (2006), Decreased gill ATPase activities in the freshwater fish Channa punctata (Bloch) exposed to a diluted paper mill effluent. Ecotoxicol. Environ. Saf., 65, 62-66.

Pikkarainen, A-L., (2006), Ethoxyresorufin-Odeethylase (EROD) activity and bile metabolites as contamination indicators in Baltic Sea perch: Determination by HPLC. Chemosphere, 65, 18881897.

Pimpão, C., Zampronio, A. R., Silva de Assis, H. C. (2007), Effects of sublethal doses of deltamethrin on hematological parameters and enzymatic activity in Ancistrus multispinis (Pisces, Teleostei). Pest. Biochem. Physiol., 88, 122-127.

Reddy, P. M., Philip, G. H., (1994), In vivo inhibition of AchE and ATPase activities in the tissues of freshwater fish, Cyprinus carpio exposed to techinal grade cypermethrin, Bull. Environ. Contam. Toxicol., 52, 619-626.

Sayeed, I., Parvez, S., Pandey, S., Bin-Hafeez, B., Haquee, R., Raisuddin, S. (2003), Oxidative stress biomarkers of exposure to deltamethrin in freshwater fish, Channa punctatus Bloch. Ecotoxicol. Environ. Saf., 56, 295-301.

Silva de Assis, H. C. (1998), Der Einsatz von Biomarkern zur summarischen Erfassung von Gewässerverschmutzungen. $\mathrm{PhD}$ Thesis Technical University of Berlin, Alemanha.

Stegeman, J. J., Binder, R. L., Orren, A. (1979), Hepatic and extrahepatic microssomal electron transport components and mixed-function oxigenases in the marine fish Stenotomus versicolor. Biochem. Pharmacol., 28, 3431-3439.

Stegeman, J. J., Binder, R. L., Orren, A. (1979), Hepatic and extrahepatic microssomal electron transport components and mixed-function oxigenases in the marine fish Stenotomus versicolor. Biochem. Pharmacol., 28, 3431-3439.

Stegeman, J. J., Hahn, M. E. (1994), Biochemistry and molecular biology of monooxigenases: current 
perspectives on forms, functions and regulation of cytochrome $\mathrm{P} 450$ in aquatic species. In- Aquatic Toxicology: Molecular, Biochemical and Cellular Perspectives. ed. D. C. Mallins, G. K. Ostrander, CRC Press, Boca Raton, FL, pp. 87-206.

Sturm, A., Silva de Assis, H. C., Hansen, P. D. (1999), Cholinesterase of marine teleost fish: enzymological characterization and potential use in the monitoring of neurotoxic contamination. Mar. Environ. Res., 47, 389-398.

Szegletes, T., Polyhos, C., Bálint, T., Rady, A., Lang, G., Kufcsak, O., Nemcsok, L. (1995), In vivo effects of deltamethrin on some biochemical parameters of cap (Cyprinus carpio L.) Environ. Monit. Assess., 35, 97-111.

Therien, A., Blostein, R. (2000). Mechanisms of sodium pump regulation. Am. J. Physiol. Cell Physiol., 279, 541-566.
Ural, M. S., Sağlam, N. (2005), A study on the acute toxicity of pyrethroid deltamethrin on the fry rainbow trout (Oncorhynchus mykiss Walbaum, 1792) Pest. Biochem. Physiol., 83, 124-131.

Villarini, M., Moretti, M., Pasquini, R., ScassellatiSforzolini, G., Fatigoni, C., Silvano Monarca, M.M., Rodriguez, A. V. (1998). In vitro genotoxic effects of the insecticide deltamethrin in human peripheral blood leukocytes: DNA damage ('comet assay') in relation to the induction of sister-chromatid exchanges and micronuclei. Toxicol., 130, 129-139.

Walker, C. H., Hopkin, S. P., Sibly, R. M., Peakall, D. B. (1996), Principles of Ecotoxicology. Taylor and Francis, London, pp.321.

Received: July 09, 2007; Revised: December 28, 2007; Accepted: March 27, 2009. 